\title{
KEBERADAAN KEPUTUSAN MAJELIS UTAMA DESA PAKRAMAN BALI (MUDP) BALI No. 01/Kep/Psm-3/MDP Bali/X/2010 DI DESA ADAT LAMBING
}

\author{
Gusti Ayu Dewi Irna Yanthi, I Nyoman Putu Budiartha, Ketut Sukadana \\ Fakultas Ilmu Hukum Universitas Warmadewa, Denpasar - Bali, Indonesia \\ dewiirnayanthi19@gmail.com, budiartha.fhwjurnal@gmail.com, sukadanaketut1966@gmail.com
}

\begin{abstract}
Abstrak
Pewarisan di Bali menganut asas Patrilineal dimana anak laki-laki yang berhak mewaris sementara wanita tidak mempunyai hak mewaris. Namun Majelis Utama Desa Pakraman (MUDP) Bali membuat terobosan baru dimana wanita Bali dapat mewaris. Tujuan penelitian ini adalah mendeskripsikan bagaimana kedudukan hak mewaris wanita berdasarkan hukum waris adat di Bali dan menggambarkan keberadaan Keputusan Majelis Utama Desa Pakraman Bali (MUDP) Bali No.01/Kep/Psm-3/MDP Bali/X/2010 di Desa Adat Lambing. Penelitian ini menggunakan menggunakan metode penelitian empiris dengan menyajikan data secara kualitatif, Hasil penelitian menyatakan dalam awig-awig desa Adat Lambing kedudukan wanita bukan sebagai ahli waris. Sedangkan keberadaan keputusan Pesamuhan Agung III Majelis Utama Desa Pakraman pelaksanaanya belum berlaku sepenuhnya. Kurangnya sosialisasi serta berlakunya awig-awig sebagai suatu aturan yang mengikat menyebabkan belum terlaksananya keputusan tersebut.
\end{abstract}

Kata kunci: Hak Waris, Hukum Adat Bali, Wanita

\begin{abstract}
Inheritance in Bali adheres to the Patrilineal principle where men have the right to inherit while women do not have the right to inherit. However, the Main Council of Pakraman Village (MUDP) Bali made a new breakthrough in which Balinese women can inherit. The purpose of this study is to describe the position of women's inheritance rights based on customary inheritance law in Bali and to describe the existence of the Bali Pakraman Village Main Council Decree (MUDP) No.01 / Kep / Psm-3 / MDP Bali / X / 2010 in Lambing Traditional Village. This study used an empirical research method by presenting data qualitatively. The results of the study stated that in the awig-awig of the traditional village of Lambing, the position of women was not as heirs. Meanwhile, the implementation of the decision of Pesamuhan Agung III of the Main Assembly of Pakraman Village has not been fully implemented. Lack of socialization and the enactment of awig-awig as a binding rule have resulted in the inability to implement this decision.
\end{abstract}

Keywords: Inheritance rights, Balinese Customary Law, Women

\section{PENDAHULUAN}

Asas kekeluargaan dalam Hukum Adat adalah bagian utama yang terpenting dalam pewarisan. Di Indonesia hukum waris memiliki sifat majemuk. Hal tersebut disebabkan karena di Indonesia sendiri Undang-undang mengenai Hukum Waris Nasional masih belum diatur dan belum berlaku bagi seluruh rakyat di Indonesia (Fauzi, 2016; Nasution, 2018). Hukum adat waris adalah hukum yang memuat peraturan yang mangatur proses penerusan seta pengalihan barang-barang baik berupa harta materiil maupun non materiil.

Di Bali dalam perkembangannya hak waris bagi wanita mulai diperhatikan dalam masyarakat adat. Namun wanita sering mendapat perlakuan diskriminasi sebelum seorang wanita mulai diperhatikan sebagai ahli waris (Hendrako, 2015; Sudantra, Sukerti, \& Dewi, 2015; Sukerti \& Ariani, 2014). Sistem kekerabatan patrilineal atau mengikuti garis keturunan laki-laki membuat kedudukan laki-laki lebih tinggi dari wanita. Hal tersebut memunculkan deskriminasi gender dalam hukum adat Bali. Fenomena tersebut adalah seorang wanita dianggap nomor dua dalam keluarga karena beranggapan seorang wanita akan kawin keluar meninggalkan rumah orangtuanya. Dalam awig-awig desa Adat telah diatur bahwa ahli waris adalah mengikuti garis keturunan laki-laki (purusa) (Adnyana, 
2018; Ratmini, 2015; Setyawati, 2017). Namun Majelis Utama Desa Pakraman (MUDP) Bali dalam perkembangan terakhir membuat suatu terobosan bahwa seorang wanita Bali layak mendapat warisan.

Berdasarkan uraian latar belakang di atas, penelitian ini dilakukan dengan tujuan mendeskripsikan bagaimana kedudukan hak mewaris wanita berdasarkan hukum waris adat di Bali dan menggambarkan keberadaan Keputusan Majelis Utama Desa Pakraman Bali (MUDP) Bali No.01/Kep/Psm-3/MDP Bali/X/2010 di Desa Adat Lambing.

\section{METODE}

Penelitian ini menggunakan metode penelitian empiris, yang mana dalam penelitian digunakan fakta nyata yang terjadi di lapangan. Pendekatan yang digunakan adalah pendekatan sosiologi hukum. Sumber data penelitian ini adalah beberapa informan di Desa Adat Lambing dan beberapa dokumentasi. Teknik pengumpulan data yang digunakan yaitu wawancara yang disertai dengan dokumentasi. Data yang sudah terkumpul dianalisis menggunakan metode deskriptif dan disajikan secara informal.

\section{HASIL DAN PEMBAHASAN}

1. Kedudukan Hak Waris Bagi Wanita Berdasarkan Hukum Waris Adat Bali

Erfrecht adalah istilah hukum waris dalam perdata barat. Dalam Pasal 830 KUHPerdata disebutkan bahwa hukum waris adalah hukum yang mengatur kedudukan hukum harta kekayaan seseorang setelah ia meninggal, terutama berpindahnya harta kekayaan itu kepada orang lain (Triwulan, 2008).

Hukum adat waris meliputi norma hukum yang menetapkan harta kekayaan baik materiil maupun immateriil yang diserahkan pada ahli waris serta mengatur mengenai saat, cara, dan proses peralihan (Wignjodipuro, 2010).

Wanita Bali pada hakekatnya bukan merupakan seorang ahli waris, namun dalam kenyataan masyarakat adat Bali, wanita berhak atas kekayaan orang tuanya namun tidak berhak menjadi ahli waris. Dalam masyarakat adat Bali sebuah keluarga sering merasa khawatir apabila hanya memiliki keturunan wanita dan tidak memiliki keturunan laki-laki bahkan menganggap hal tersebut sebagai malapetaka (Wibawa, 2006).

Karena di Bali menganut asas kekeluargaan Patrilineal dalam pewarisan, keluarga yang tidak mempunyai anak laki-laki dan hanya mempunyai anak perempuan akan berada dalam masalah. Sehingga mengenai masalah tersebut, dalam Hukum adat Bali dikenal dengan melaksanakan perubahan terhadap status seorang wanita dimana melalui perkawinan seorang wanita dianggap sebagai purusa (laki-laki). Perubahan status tersebut terjadi apabila seorang wanita melaksanakan perkawinan kaceburin (Warsita, 2020). Dengan demikian status atau kedudukan seorang wanita dikatakan sebagai sentana rajeg.

Dengan terjadinya perubahan terhadap status tersebut, bagi keluarga yang hanya memiliki anak perempuan tanpa anak laki-laki tetap dapat memiliki ahli waris. Namun dari perubahan terhadap status tersebut maka akan ada perubahan juga terkait dengan hak serta kewajiban dari ahli waris dalam keluarga.

Dalam masyarakat Adat Bali pewarisan sudah mengalami perkembangan terkait persamaan wanita dalam pewarisan dimana hal tersebut diatur dalam Keputusan Majelis Utama Desa Pakraman Bali (MUDPB) No.01/Kep/Psm-3/MUDP Bali/X/2010 tertanggal 15 Oktober 2010 terkait hasil Pesamuhan Agung III MUDP Bali No.01/Kep/Psm-3/MUDP Bali/X/2010 dimana ditentukan yaitu: setelah tahun 2010 wanita Bali mendapat hak waris purusa (laki-laki) sesudah dikurangi 1/3 sebagai harta pusaka serta untuk pelestarian. Bagi wanita Bali yang melaksanakan pindah agama, tidak memiliki hak atas waris. Namun jika orang tua secara sukarela dan ikhlas memberikan bekal atau jiwa dana hal tersebut masih diperbolehkan.

Alasan yang menjadi dasar dikeluarkannya Keputusan Majelis Utama Desa Pakraman Bali (MUDPB) No.01/Kep/Psm-3/MUDP Bali/X/2010 adalah memberi perlindungan bagi wanita yang telah berkeluarga agar memiliki keharmonisan dalam mengarungi rumah tangga, serta dengan adanya Keputusan Pesamuhan Agung III MUDP Bali seorang wanita mendapatkan kepastian hukum serta kesetaraan gender dalam halnya pewarisan.

Berdasarkan hal tersebut diatas, Pasamuhan Agung III Majelis Desa Pakraman Bali terhadap harta pusaka dan gunakaya diputuskan kedudukan suami istri dan anak yaitu: 
1. Suami, istri, beserta saudara laki-laki dari suami maupun istri, memiliki kedudukan yang setara untuk menjamin bahwa harta pusaka tersebut dapat diturunkan bagi anak beserta cucunya untuk pemeliharaan dan pelestarian warisan immaterial,

2. Selama melaksanakan suatu perkawinan, baik suami maupun istri, memiliki kedudukan setara terhadap harta gunakaya-nya (harta yang didapatkan selama suami istri tersebut masih dalam ikatan perkawinan),

3. Anak kandung baik laki-laki maupun wanita dan anak angkat baik laki-laki maupun wanita sebelum melaksanakan perkawinan, memiliki kedudukan yang setara dalam hal terkait harta gunakaya orang tuanya,

4. Anak kandung (laki-laki maupun perempuan) dan anak angkat (laki-laki maupun perempuan) memiliki hak atas harta gunakaya orang tuanya setelah dikurangi $1 / 3$ sebagai harta bersama (duwe tengah ), yang dikuasai atau bukan dimiliki oleh anak yang melanjutkan swadharma atau tanggung jawab orang tuanya (nguwubang)

5. Anak dengan status kapurusa memiliki hak waris atas satu bagian harta waris dan anak dengan status pradana/ninggal kedaton memiliki hak terbatas atau sebagian dari harta warisan yang anak dengan status purusa dapatkan,

6. Anak yang masih dikandung dalam hal pemberian waris, memiliki hak yang sama sebagaimana dengan anak yang telah dilahirkan, selama anak yang dikandung tersebut dilahirkan hidup,

7. Tidak memiliki hak waris, akan tetapi bisa mendapatkan bekal (jiwa dana) dari orang tua sebagai harta gunakaya sepanjang ahli waris tidak dirugikan, hal tersebut berlaku bagi anak yang ninggal kedaton sepenuhnya.

Dengan perubahan tersebut wanita Bali yang telah melangsungkan pernikahan namun masih menjadi pradhana seharusnya memilki hak dalam mewaris baik harta orang tuanya ataupun suaminya. Karena menyangkut tradisi, dalam implementasinya memerlukan waktu yang tidak singkat. Sistem waris adat Bali dalam pelaksanaanya terkait kedudukan wanita dalam sistem pewarisan Adat di Bali masih berdasarkan kepada hukum adat lama yang ada dari zaman dulu yang mana wanita tidak memiliki kedudukan sebagai ahli waris sehingga tidak memiliki hak mewarisi harta yang ditinggalkan oleh orang tua maupun suaminya. Walaupun seorang wanita tidak memiliki kedudukan sebagai ahli waris namun selama tidak terputusnya hak seorang wanita dengan keluarganya maka wanita masih memiliki hak memakai dan manikmati sebagian harta waris orang tuanya.

Berdasarkan konsep terebut dapat disimpulkan walaupun wanita menurut hukum waris adat Bali dalam hakikatnya bukan sebagai ahli waris namun seorang wanita berhak memperoleh sebagian dari warisa orang tuanya, pada prakteknya pemberian itu menggunakan beberapa istilah yaitu: bekal hidup atau harta tetatadan, jiwadana atau juga disebut pangupajiwa. Jiwa dana adalah harta bawaan wanita yang kawin keluar dan diharapkan dengan harta tersebut wanita mempunyai status dengan keluarga barunya (keluarga suami) (Arta, Sudiatmika, \& Windari, 2018).

\section{Keberadaan Keputusan Majelis Utama Desa Pakraman (MUDP) Bali No. 01/Kep/Psm-3/MDP Bali/X/2010 di Desa Adat Lambing}

Kedudukan wanita Hindu Bali sebagai ahli waris pada Keputusan Pesamuhan Agung III Majelis Utama Desa Pakraman keberadaan pelaksanaannya di Desa Adat Lambing belum berlaku secara efektif. Bendesa Adat Lambing I Gusti Putu Arka berpendapat dalam melaksanakan kewajiban maupun bertingkah laku lagi krama Desa Adat Lambing terdapat beberapa aturan yang dianggap sebagai panutan krama Desa Adat Lambing yaitu : awig-awig, perarem, sima, dan lekita. Dari aturanaturan tersebut awig-awig merupakan aturan utama yang mengikat masyarakat (Wawancara dengan Bendesa Adat Lambing I Gusti Putu Arka pada tanggal 1 September 2020).

Adapun dalam awig-awig hal-hal yang berkaitan dengan pewarisan diatur dalam beberapa Pawos sebagai berikut:

1. Bunyi Pawos 56 sarga (1):

Santana wenten kalih pawos, sane kaucap pratisentana miwah sentana paperasan;

Arti bebasnya : Seorang anak dapat dibedakan sebagai anak kandung serta anak angkat.

2. Bunyi Pawos 56 sarga (6):

Sang sang karsayang santana rajeg inucap mawit saking; 
a. Pratisantana wadon tunggal utawi silih sinunggil pratisantana wadon yening makasami pratisentana wadon;

b. Sampun kamenggahang dados pratisantana (purusa)

c. Kapawiwaha kaceburin, kautsahayang antuk jadma sane magama Hindu utawi jadma sane magama siosan sane sampun ngalaksanayang pamarisudha raga utawi sudi wadani;

d. Sane kamanggehang santana rajeg patut masadok ring prajuru banjar tur kelian banjar nyiarang ring banjar saha ngaturang ring prajuru desa adat;

Arti bebasnya : yang dapat dikatakan sebagai ahli waris utama yaitu ;

a. Anak wanita tunggal atau salah satu anak wanita jika semua anak adalah wanita;

b. Sudah ditetapkan sebagai anak dengan status purusa;

c. Dilakukan upacara kawin kaceburin, dan diusahakan beragama Hindu atau agama lain tetapi sudah dilakukan upacara sudhi wadani;

d. Anak yang diangkat sebagai sentana rajeg wajib dilaporkan pada prajuru selanjutnya dilakukan siar di banjar;

3. Bunyi Pawos 64:

Munggwing waris kawaris ring desa adat kamargiang makadi ring sor :

(1) Risampun kalaksanayang pitra yajnya lan hutang-hutang pewaris buntas katawur, wawu warisan dados kaepah.

(2) Para ahli waris sami polih pahan sangkaning pagunakaya, sajawaning karang utawi tegal ayahan desa kaemong antuk ahli waris sane sinanggeh krama ngarep.

(3) Silih sinunggil ahli waris kengin tan polih pahan prade:

a. Nilar kawitan lan sesananing agama

b. Alpaka guru rupaka

c. Sentana rajeg kesah mawiwaha utawi pratisantana nyeburin soang-soang kabawos ninggal kedaton.

(4) Boya ahli waris, kengin muponin hasil manut dudonan, luire :

a. Santana luh, salami durung kesah mawiwaha;

b. Balu luh wiadin muani nyeburin (soang-soang boya santana).

(5) Pawaris kengin maweweh rikala maurip pinaka jiwa dana, tatadan utawi bekel, maka cihna paweweh tetep ring okane sane kesah mawiwaha.

Arti bebasnya : Proses pewarisan di Desa Adat ini dilakukan sebagai berikut :

(1) Sudah dilakukan upacara pitra yadnya dan pelunasan hutang piutang, warisan baru dapat dibagi.

(2) Para ahli waris semua mendapatkan bagian kecuali karang (tanah ayahan desa/kebun) dikuasai oleh ahli waris waris yang tercantum sebagai warga inti.

(3) Salah satu ahli waris tidak akan dapat warisan jika:

a. Meninggalkan keluarga dan leluhur dan agama Hindu

b. Durhaka terhadap orang tua

c. Ahli waris yang kawin keluar

(4) Bukan sebagai ahli waris, namun memiliki hak untuk menikmati, yaitu:

a. Wanita, sebelum kawin keluar.

b. Janda atau duda yang dalam posisi kawin nyeburin.

(5) Pewaris dapat memberikan harta ketika masih hidup berupa, jiwa dana, tatadan, atau bekal yang bermakna sebagai bentuk rasa sayang kepada anaknya yang menikah keluar.

I Gusti Putu Arka menjelaskan khususnya di Kabupaten Badung belum adanya sosialisasi mengenai Keputusan Majelis Utama Desa Pakraman (MUDP) Bali Nomor 01/Kep/Psm-3/Mdp Bali/X/2010 tentang kedudukan seorang wanita Bali dalam keluarga terkait dengan pewarisan. Dalam pelaksanaanya, selain adanya sosialisasi juga perlu suatu dukungan dari Bendesa Adat dan Prajuru/Pengurus Adat.

Mengingat dalam awig-awig desa adat belum diatur mengenai hak mewaris wanita, Keputusankeputusan Pesamuhan Agung tersebut belum berlaku sebagai hukum yang nyata. Menurut Bendesa Adat I Gusti Putu Arka walaupun belum adanya sosialisasi terkait Keputusan Pesamuhan Agung III MUDP Bali melalui keputusan tersebut hak seorang wanita sudah dihormati dengan adanya kebijakan 
memberikan kesempatan pada seorang wanita sebagai pewaris dalam keluarganya (Wawancara dengan Bendesa Adat I Gusti Putu Arka pada tanggal 10 November 2020).

Selain itu, Kelian Banjar Dinas Lambing I Gusti Putu Anom menyatakan pemberian waris bagi wanita dianggap telah menghormati hak seorang wanita pada jaman sekarang, namun dalam pelaksanaannya pemberian waris harus mengutamakan awig-awig serta perarem di Desa Adat (Wawancara dengan Kelian Banjar Dinas Lambing I Gusti Putu Anom tanggal 3 Desember 2020). Masyarakat Desa Adat Lambing I Gusti Made Susila berpendapat dengan adanya Keputusan Pesamuhan Agung III MUDP Bali, keputusan tersebut memberikan kepastian hukum serta kesetaraan bagi wanita dan laki-laki, sehingga perlu dilaksanakan selama tidak bertentangan dengan kebutuhan hukum masyarakat. Walau demikian dalam pemberian waris beliau masih akan mengikuti awig-awig sebagai aturan Desa Adat yang utama (wawancara dengan masyarakat adat lambing I Gusti Made Susila tanggal 4 Desember 2020).

Keberadaan Keputusan Majelis Utama Desa Pakraman (MUDP) Bali Nomor 01/Kep/Psm3/Mdp Bali/X/2010 dalam pelaksanaanya keputusan tersebut belum terlaksana dengan sepenuhnya, adapun belum tersosialisasikannya keputusan adalah faktor belum terlaksananya keputusan tersebut di Desa Adat Lambing sehingga masyarakat belum memahami isi dari Putusan Pesamuhan Agung III MUDP Bali tersebut. Selain itu dalam masyarakat Adat Lambing awig- awig masih menjadi aturan yang utama.

\section{SIMPULAN DAN SARAN}

\section{Simpulan}

Ada beberapa simpulan yang dapat dibuat berdasarkan hasil dan pembahasan yang dipaparkan di atas, yaitu: pertama, Hukum Waris Adat di Bali mengikuti asas kapurusa yang artinya keturunan atau anak laki-laki yang menerima warisan. Kedudukan wanita Hindu di Bali pada hakekatnya bukan sebagai ahli waris. Namun bagi keluarga yang hanya memiliki anak perempuan tanpa anak laki- laki masih akan memiliki ahli waris yang akan mewarisi harta kekayaannya. Hal tersebut dilakukan dengan melangsungkan perkawinan kaceburin, dengan melangsungkan perkawinan tersebut maka status seorang wanita dari peadhana akan berubah menjadi purusa (laki-laki). Dengan demikian keluarga yang hanya memiliki anak perempuan tanpa anak laki-laki masih akan memiliki ahli waris dalam keluarganya. Kedua, Keberadaan Keputusan Pesamuhan Agung III Majelis Utama Desa Pakraman Bali Nomor 01/Kep/Psm-3/MDP Bali/X/2010 di Desa Adat Lambing dalam pelaksanaanya belum terlaksana secara sepenuhnya. Hal tersebut dikarenakan kurangnya sosialisasi pada masyarakat serta masih kuatnya awig-awig sebagai hukum adat yang berlaku dalam masyarakat Bali di mana bagi masyarakat adat Lambing awig-awig merupakan aturan utama masyarakat.

\section{Saran}

Ada juga beberapa saran yang perlu disampaikan berdasarkan hasil penelitian ini, yaitu: pertama, kepada masyarakat, Keputusan Majelis Utama Desa Pakraman Bali tersebut dibuat berdasarkan perkembangan zaman. Jadi, masyarakat diharapkan dapat membuka pola pikir terkait adanya perubahan hukum. Sehingga suatu keputusan dapat terlaksana secara efektif. Kedua, kepada Majelis Utama Desa Pakraman, perlu melakukan sosialisasi terhadap suatu keputusan diharapkan agar masyarakat memahami isi dari keputusan yang dikeluarkan sehingga dalam pelaksanaannya keputusan tersebut dapat berlaku secara efektif dan aplikatif.

\section{DAFTAR PUSTAKA}

Adnyana, I. N. P. (2018). Status dan Kedudukan Anak Laki-Laki Cacat Fisik Menurut Hukum Adat Bali di Desa Pakraman Tabola Kecamatan Sidemen, Kabupaten Karangasem. VIDYA WERTTA, 1(2), 78-83.

Arta, I. K. K., Sudiatmika, K., \& Windari, R. A. (2018). Realisasi Keputusan Pesamuhan Agung III MUDP Bali terhadap Pewarisan Anak Perempuan Bali Aga di Kabupaten Buleleng. Jurnal Komunitas Yustitia Universitas Pendidikan Ganesha, 1(1).

Fauzi, M. Y. (2016). Legislasi Hukum Kewarisan di Indonesia. Jurnal Pengembangan Masyarakat Islam, 9(2), 53-76.

Hendrako, E. (2015). Hak Waris Anak Perempuan terhadap Harta Peninggalan (Kasus Putusan MA RI No. 4766/Pdt/1998). Lex Privatum, 3(1), 84-94.

Nasution, A. (2018). Pluralisme Hukum Waris di Indonesia. Al-Qadhâ, 5(1), 20-30.

Ratmini, N. K. S. (2015). Hak Warisan dan Hubungannya dengan Daha Tua Menurut Hukum Adat Bali. Jurnal 
Magister Hukum Udayana, 4(2), 392-407.

Setyawati, N. K. (2017). Kedudukan Perempuan Hindu Menurut Hukum Waris Adat Bali dalam Perspektif Kesetaraan Gender. Jurnal Penelitian Agama Hindu, 1(2), 618-625.

Sudantra, I. K., Sukerti, N. N., \& Dewi, A. A. I. A. A. (2015). Pengaturan Perkawinan pada Gelahang Dalam Awig-Awig Desa Pakraman. Jurnal Magister Hukum Udayana (Udayana Master Law Journal), 4(3), 575-587.

Sukerti, N. N., \& Ariani, I. G. A. A. (2014). Perkembangan Kedudukan Perempuan dalam Hukum Adat Waris Bali (Studi di Kota Denpasar). Jurnal Magister Hukum Udayana, 6(2), 243-258.

Triwulan, T. (2008). Hukum Perdata dalam Sistem Hukum Nasional. Jakarta: Kencana.

Warsita, I. P. A. (2020). Hak Wanita Tunggal terhadap Warisan dalam Hukum Adat Bali. Jurnal Analogi Hukum, 2.

Wibawa. (2006). Wanita Hindu Sebuah Emansipasi Kebablasan. PT. Empat Warna Komunikasi.

Wignjodipuro, S. (2010). Pengantar dan Asas-Asas Hukum Adat. Jakarta: PT. Toko Buku Gunung Agung. 